CLINICAL STUDY

\title{
Fibroblast growth factor receptor 1 (FGFR1) is over-expressed in benign prostatic hyperplasia whereas FGFR2-IIIc and FGFR3 are not
}

\author{
Sophie Boget, Catherine Cereser, Parviz Parvaz, Albert Leriche ${ }^{1}$ and André Revol \\ Department of Endocrine and Molecular Biochemistry, Faculty of Pharmacy, University LYON I, Lyon, France and ${ }^{1}$ Department of Urology, \\ Henry Gabrielle Hospital, Saint Genis Laval, France \\ (Correspondence should be addressed to A Revol, Laboratoire de Biochimie Endocrinienne et Moléculaire, Faculté de Pharmacie, Université LYON I, \\ 8, avenue Rockefeller, 69373 LYON Cedex 08, France; Email: sophieboget@hotmail.com)
}

\begin{abstract}
Objective: Benign prostatic hyperplasia (BPH) is one of the major public health problems among men: $50 \%$ of men over 55 are concerned with this disease. Prostate growth is under the control of androgens which act by means of several growth factors such as fibroblast growth factors (FGFs), epidermal growth factor and transforming growth factor $\beta$. Basic FGF (bFGF) has been shown to stimulate prostatic stromal growth. In BPH, bFGF concentration is two- to threefold higher than in normal prostate. In this work, the bFGF receptors (FGFR1, FGFR2-IIIc and FGFR3) genes expression was evaluated to study the correlation between the expression of bFGF receptors and induction of $\mathrm{BPH}$.

Methods: The expression of FGFRs was analyzed by RT-PCR, FGFR1 was localized by immunohistochemistry and protein expression was evaluated by Western blot.

Results: A two- to eightfold over-expression of FGFR1 was observed in BPH compared with normal prostates. FGFR1 was localized in the stroma both in BPH and in normal prostates and 1.5- to 2.5fold over-expression of the protein was observed. The expression of FGFR2-IIIc and FGFR3, more secondary receptors, was not significantly different between $\mathrm{BPH}$ and normal prostates. Conclusions: bFGF receptors and particularly FGFR1 seem to be involved in the induction and evolution of $\mathrm{BPH}$ and probably potentiate bFGF over-expression effects in $\mathrm{BPH}$.
\end{abstract}

European Journal of Endocrinology 145 303-310

\section{Introduction}

Benign prostatic hyperplasia $(\mathrm{BPH})$ is one of the most common diseases among aging men (1), and is responsible for the main surgical intervention on men over 55 years old (2). The initial lesion of BPH seems to be a stromal nodule in the transition zone of the prostate that induces proliferation and organization of epithelial cells into new acini (3). Age is the principal risk factor since the prevalence of $\mathrm{BPH}$ is approximately $8 \%$ at age $25-30,50 \%$ at age $51-60$ and $90 \%$ at age 85 and over (3). Relatively little is known about growth regulation of the prostate and the mechanisms involved in $\mathrm{BPH}$. The mechanisms underlying the development of BPH seem to be similar to those responsible for normal growth (3). Prostatic hyperplasia appears when the concentration of androgens decreases in man; but growth factors seem to act in a disregulated manner, as if they have escaped from androgen control (4).

Prostate regulation is under the control of androgens (5- $\alpha$-dihydrotestosterone mainly) and, locally, prostate growth depends on positive control by growth factors $(5,6)$ such as fibroblast growth factors (FGFs) (7) (basic fibroblast growth factor (bFGF or FGF2), keratinocyte growth factor (KGF or FGF7)...), epidermal growth factor (EGF), and transforming growth factor $\beta$ (TGF $\beta$ ) which acts as an inhibitor for both stromal and epithelial growth (8).

In $\mathrm{BPH}$, the local concentration of bFGF is two- to threefold higher than in normal prostate $(9,10)$. This fact suggests that bFGF is probably involved in BPH.

In the prostate, three of the four FGFs receptors are expressed: FGFR1 (which is the principal receptor for bFGF), FGFR2 in two isoforms (FGFR2-IIIb, which is the receptor for KGF, and FGFR2-IIIc, a receptor for bFGF) and FGFR 3 (which is a receptor for acidic FGF (aFGF) and FGFs in general).

FGFR1 concentration seems to increase in BPH (11) but conflicting studies exist about FGFR1 localization (epithelium (12), both stroma and epithelium (13) or only stroma (14-16)). However, FGFR2-IIIc and FGFR3 expressions were not quantified (Table 1). 
Table $1 \mathrm{bFGF}$ receptors in BPH in the literature.

\begin{tabular}{|c|c|c|c|c|c|c|}
\hline \multirow[b]{2}{*}{ Reference } & \multicolumn{2}{|c|}{ FGFR1 } & \multicolumn{2}{|c|}{ FGFR2-IIIC } & \multicolumn{2}{|r|}{ FGFR3 } \\
\hline & Tissue localization & $\begin{array}{l}\text { Expression in BPH } \\
\text { compared with } \\
\text { normal prostates }\end{array}$ & $\begin{array}{c}\text { Tissue } \\
\text { localization }\end{array}$ & $\begin{array}{l}\text { Expression in BPH } \\
\text { compared with } \\
\text { normal prostates }\end{array}$ & $\begin{array}{l}\text { Tissue } \\
\text { localization }\end{array}$ & $\begin{array}{l}\text { Expression in } \\
\text { BPH compared with } \\
\text { normal prostates }\end{array}$ \\
\hline Story (4) & Stroma & No difference & Stroma & No difference & ND & ND \\
\hline $\begin{array}{l}\text { Hamaguchi et al. } \\
\text { (11) }\end{array}$ & $\begin{array}{l}\text { Stroma and } \\
\text { epithelium (weak) }\end{array}$ & $\begin{array}{l}\text { 5-fold over-expression } \\
\text { in BPH }\end{array}$ & ND & ND & ND & ND \\
\hline $\begin{array}{l}\text { Ittmann \& Mansukhani } \\
\text { (14) }\end{array}$ & Stroma & ND & Stroma & ND & $\begin{array}{l}\text { Stroma and } \\
\text { epithelium }\end{array}$ & ND \\
\hline Saez et al. (16) & $\begin{array}{l}\text { Stroma and } \\
\text { epithelium (weak) }\end{array}$ & ND & $\begin{array}{l}\text { Stroma and } \\
\text { epithelium }\end{array}$ & ND & ND & ND \\
\hline This study & Stroma & $\begin{array}{l}\text { 2- to 8-fold } \\
\text { over-expression } \\
\text { in BPH }\end{array}$ & ND & No over-expression & ND & No over-expression \\
\hline
\end{tabular}

ND, not determined.

This study evaluated the expression of the three receptors by reverse-transcription and polymerase chain reaction (RT-PCR) to detect a possible increase in receptor mRNA in agreement with bFGF. FGFR1 localization was studied by immunohistochemistry to find whether its distribution was different from normal tissue. Western blot analysis was performed for FGFR1 to observe if the protein expression had the same profile as the gene expression.

This work confirmed the increase in FGFR1, but localized it in the prostatic stroma only, and showed no significant difference in FGFR2-IIIc and FGFR3 genes expression between hyperplastic and normal tissues.

\section{Materials and methods}

\section{Tissue samples}

Tissue samples of BPH were collected from 25 men aged 48 to 79 undergoing transurethral resection of the prostate. For each patient, some clinical and biological information was provided by the urological department, indicating the age of the patient, weight, specific treatment, a possible associated disease, date of the first symptoms, prostate weight, prostate specific antigen (PSA) blood concentration, sampling weight and prostate zone origin. The samples were analyzed by the Pathological Anatomy Department to define the microscopic structure of the hyperplasia (stromal or glandular) and to detect a possible cancer which was an exclusion criterion in our study. Only 2 hyperplastic prostates out of 25 were glandular, the 23 others were mixed (stroma plus glandular), which is the most common type. Normal tissues were obtained from 8 patients aged 21 to 46 years without prostatic disease and undergoing vesical surgery. Eight normal or pathological prostate fragments of about 0.1 to $1 \mathrm{~g}$ each were randomly sampled during the surgical intervention. Sampling was limited as most of the tissue had to be checked in the Pathological Anatomy
Department. For immunohistochemistry, three fragments were fixed in $4 \%$ paraformaldehyde, dehydrated in alcohol and then paraffin embedded. For RT-PCR and Western blot analysis, five fragments were immediately frozen and kept at $-80^{\circ} \mathrm{C}$.

\section{RNA extraction and reverse-transcription}

RNA was extracted from small amounts of frozen tissues with Trizol (Gibco BRL, Life Technologies, Gaithersburg, MD, USA). The extracted RNA was treated with 2 units of DNAse I (Gibco BRL) to eliminate contaminant DNA, and was purified by sequential extraction with phenol-chloroform. The RNA pellet was diluted in Tris-EDTA 10:1, quantified by absorptiometry at $260 \mathrm{~nm}$ (GeneQuant II spectrophotometer, Pharmacia Biotech, Uppsala, Sweden) and stored at $-20{ }^{\circ} \mathrm{C}$. One microgram total RNA was reverse-transcribed into cDNA at $42{ }^{\circ} \mathrm{C}$ for $60 \mathrm{~min}$ in PCR buffer $(16.6 \mathrm{mmol} / \mathrm{l}$ ammonium sulfate, $2 \mathrm{mmol} / \mathrm{l}$ $\mathrm{MgCl}_{2}, 6.7 \mu \mathrm{mol} / \mathrm{l} \mathrm{EDTA}, 67 \mathrm{mmol} / \mathrm{l}$ Tris-HCl, $\mathrm{pH} \mathrm{8.8}$, $0.17 \mathrm{mg} / \mathrm{ml}$ BSA) with 10 units MMLV ReverseTranscriptase (Gibco BRL), $300 \mu \mathrm{mol} / \mathrm{l}$ of each dNTP (Roche Diagnostics, Meylan, France) and $1 \mathrm{mmol} / \mathrm{l}$ of downstream primers (Table 2) for bFGF receptors FGFR1, FGFR2-IIIc and FGFR3 with glyceraldehyde phosphate dehydrogenase (GAPDH) used as an internal standard due to its relatively constant expression in prostate cells.

For each reverse transcription reaction, a negative control (without Reverse-Transcriptase) was included to verify the absence of DNA contamination.

\section{Polymerase chain reaction}

Primers for RT-PCR of FGFR1, FGFR2-IIIc, FGFR3 and GAPDH were designed using human FGF receptors and GAPDH mRNAs (Table 2). The specificity of the primers was verified (Blast, GenBank) and the primers' complementarity was tested with DNAStar software (Primer 
Table 2 Primers used in reverse transcription and polymerase chain reaction.

\begin{tabular}{llcc}
\hline Gene & \multicolumn{1}{c}{ Primer sequence } & Nucleotide number & Product size (bp) \\
\hline FGFR1 & fgfr1-1 (upstream primer) 5'-GGAGGATCGAGCTCACTCGTGG-3' & $13-34$ & 421 \\
& fgfr1-2 (downstream primer) 5'-CGGAGAAGTAGGTGGTGTCAC-3' & $433-413$ & 421 \\
FGFR2-IIIC & fgfr2-1 (upstream primer) 5'-(GTTAACACCACGGACAAAGAGATTGAG-3' & $1128-1154$ & $1958-1939$ \\
& fgfr2-2 (downstream primer) 5'-AACACGGTTAATGTCATAGG-3' & $132-153$ & 331 \\
FGFR3 & fgfr3-1 (upstream primer) 5'-CGTGGGGCGAGCGGCAGAAGTC-3' & $514-491$ & 383 \\
& fgfr3-2 (downstream primer) 5'-TCCGCTCGGGCCGTGTCCAGTAAG-3' & $659-680$ & 301 \\
GAPDH & Gap1 (upstream primer) 5'-GCGGGGCTCTCCAGAACATCAT-3' & $959-939$ & \\
& Gap2 (downstream primer) 5'-CCAGCCCCAGCGTCAAAGGTG-3' & 301 \\
\hline
\end{tabular}

GAPDH, glyceraldehyde-phosphate dehydrogenase, control gene; bp, base pairs.

Select, Lasergen, London, UK). mRNA expression of FGF receptors was semi-quantified using GAPDH as an internal control. GAPDH mRNA was co-transcribed and co-amplified with bFGF receptors mRNA. The signal intensity of PCR products for FGF receptors was compared with that of GAPDH for each sample.

The PCR mixtures contained PCR buffer with $100 \mu \mathrm{mol} / \mathrm{l}$ of each of the four dNTPs (Roche Diagnostics, Meylan, France), 0.75 units of Taq DNA Polymerase (Eurobio, Les Ulis, France), 10\% DMSO, $0.8 \mathrm{mmol} / \mathrm{l}$ of each primer (Eurogentec, Seraing, Belgium) and $7 \mu$ l reverse transcription product in a total volume of $50 \mu \mathrm{l}$. Samples were amplified for 35 cycles for FGFR 1 and FGFR 3 and for 40 cycles for FGFR2-IIIc, comprising denaturation at $95{ }^{\circ} \mathrm{C}$ for $60 \mathrm{~s}$, annealing for $60 \mathrm{~s}$ at $55^{\circ} \mathrm{C}$ for FGFR $1,56{ }^{\circ} \mathrm{C}$ for FGFR2-IIIC and $59{ }^{\circ} \mathrm{C}$ for FGFR3, and elongation at $72{ }^{\circ} \mathrm{C}$ for $90 \mathrm{~s}$ for FGFR1 and FGFR2-IIIc and for $60 \mathrm{~s}$ for FGFR3. The amplification products were separated with electrophoresis, visualized by ethidium bromide and analyzed by densitometry (BioImage densitometry software, Millipore Corporation, Bradford, MA, USA). The mRNA intensity of the FGF receptors was determined by calculating the receptors/GAPDH optical density (OD) ratio.

\section{Statistics}

Statistical evaluation was performed using a nonparametric Mann-Whitney U-test. Statistical significance was inferred at $P<0.01$.

\section{Analysis and sequencing of RT-PCR products}

The amplified products for FGFR1, FGFR2-IIIc, FGFR3 and GAPDH were analyzed by electrophoresis on $1.5 \%$ agarose gel with a DNA ladder (Roche Diagnostics) as a molecular weight standard. Bands were cut off and DNA was purified using Qiaquick gel extraction kit (Qiagen, Hilden, Germany). Purified products were then analyzed by electrophoresis on a $2 \%$ agarose gel with a quantitative DNA ladder (MBI Fermentas, Hanover, MD, USA) for quantification. DNA was amplified by PCR for 25 cycles each comprising denaturation for $10 \mathrm{~s}$ at
$96{ }^{\circ} \mathrm{C}$, annealing for $5 \mathrm{~s}$ at $50{ }^{\circ} \mathrm{C}$ and elongation for 4 min at $60{ }^{\circ} \mathrm{C}$, with $1.6 \mathrm{pmol}$ of upstream primer in a total volume of $20 \mu \mathrm{l}$, using the ABI Prism DNA sequencing kit (Applied Biosystems, Perkin Elmer, Warrington, Cheshire, UK). The amplified products were purified by precipitating with 95\% and 70\% alcohol followed by centrifugations. DNA was diluted in sequencing buffer (Applied Biosystems) and purified PCR products were sequenced using an ABI Prism sequencer (Applied Biosystems) using dye-primer cycle sequencing.

Each gene sequence (Blast, internet) was compared with the sequenced amplified products using Sequence Navigator software (Applied Biosystems).

\section{Immunohistochemistry $(17,18)$}

Tissue sections $(4 \mu \mathrm{m})$ were collected on silane-coated slides. Sections were deparaffinized, rehydrated in decreasing concentrations of alcohol and washed in water. Endogenous peroxidases were inhibited by hydrogen peroxide. Biostain Biomeda kit (Biomeda, Foster City, CA, USA) was used for protein blocking and for biotin-labeled secondary antibody and streptavidinbiotin-peroxidase complex reactions. Sections were incubated with protein blocker containing goat serum (Sigma, St Louis, MO, USA). Polyclonal rabbit antibody, specific to human FGFR1, (Flg(C15); TEBU Santa Cruz, Heidelberg, Germany) (19) with no cross-reactivity for other FGF receptors (FGFR2, FGFR3, FGFR4) was used at a concentration of $0.1 \mathrm{ng} / \mu \mathrm{l}$. Sections were incubated with biotinylated secondary goat anti-rabbit antibody, followed by streptavidin-biotin-peroxidase contact. FGFR1 was stained brown by diaminobenzidine (DAB) chromogen (Microm, Francheville, France), peroxidase substrate. Stained sections were counterstained with hematoxylin (Biomeda) to demonstrate nuclei.

In all experiments, various negative controls were included to detect any non-specific coloration (primary and secondary antibody controls and streptavidinbiotin-peroxidase complex control). The primary antibody specificity was verified by preincubating it with a corresponding antigenic peptide (TEBU Santa Cruz) 
prior to immunohistochemistry; no immunostaining was observed in these sections.

\section{Western blot}

Frozen tissue fragments were cut into small pieces and crushed at $4{ }^{\circ} \mathrm{C}$ in RIPA buffer $(1 \times$ PBS with $1 \%$ Igepal (Sigma-Aldrich, St. Louis, MO, USA), 0.5\% sodium deoxycholate, $0.1 \%$ SDS and a protease inhibitor cocktail: $0.6 \mathrm{mmol} / \mathrm{l}$ phenylmethylsulfonyl sulfate (PMSF), $2 \mu \mathrm{g} / \mathrm{ml}$ aprotinin and $2 \mu \mathrm{g} / \mathrm{ml}$ leupeptin); $18 \mathrm{mmol} / \mathrm{l} \mathrm{PMSF}$ were then added and the tissue homogenate was incubated on ice for $30 \mathrm{~min}$. It was then centrifuged twice at $15000 \mathrm{~g}$ for $20 \mathrm{~min}$ at $4{ }^{\circ} \mathrm{C}$. Total protein was quantified and the cell lysate was conserved at $-70{ }^{\circ} \mathrm{C}$.

Proteins at a concentration of $2 \mathrm{mg} / \mathrm{ml}$ were denatured in $125 \mu \mathrm{l}$ Tris-HCl (0.5 mol/l, $\mathrm{pH}$ 6.8), $200 \mu \mathrm{l} 10 \%$ SDS, $50 \mu \mathrm{l} \beta$-mercapto-ethanol, $100 \mu \mathrm{l}$ $88 \%$ glycerol and boiled for $5 \mathrm{~min}$ at $100{ }^{\circ} \mathrm{C}$. One hundred micrograms total proteins were loaded on to $8 \%$ acrylamide gel (with $4 \%$ acrylamide stacking gel) and electrophoresis was carried out for $1 \mathrm{~h}$ at $130 \mathrm{~V}$. Proteins were transferred from the gel to a PVDF membrane (Amersham, Freiburg, Germany) for $1 \mathrm{~h}$ at $15 \mathrm{~V}$ and $500 \mathrm{~mA}$. The membrane was then soaked in $1 \times$ PBS containing $1 \%$ milk for $1 \mathrm{~h}$ to block nonspecific binding. It was then incubated with the primary antibody $\operatorname{Flg}(\mathrm{C} 15)$ (TEBU Santa Cruz) at 1/1000 dilution in PBS, 0.05\% Tween 20 and 1\% milk for $3 \mathrm{~h}$ at $37^{\circ} \mathrm{C}$ and washed 3 times in PBS-Tween 20 . The membrane was then incubated with horseradish peroxidase conjugated anti-rabbit antibody for $90 \mathrm{~min}$ and washed twice in PBS-Tween 20 and twice in water. ECL+ chemiluminescence substrate (Amersham) was added to the membrane for $5 \mathrm{~min}$. The membrane was drained and exposed for $15 \mathrm{~min}$ to a film. The bands were analyzed densitometrically after development of the film.

Negative controls without primary and secondary antibodies were also included to detect any non-specific bands. A negative control with an Flg(C15) corresponding antigenic peptide was added to verify the primary antibody specificity.

\section{Results}

\section{RT-PCR}

For each patient, 2 samples of prostatic tissue were obtained, each sample being tested in triplicate. Between 2 fragments of 2 different regions of the prostate of the same patient, the standard deviation for each mRNA expression was slight (5 to $15 \%$ of the mean value), showing some homogeneity in the prostatic tissue for each patient.
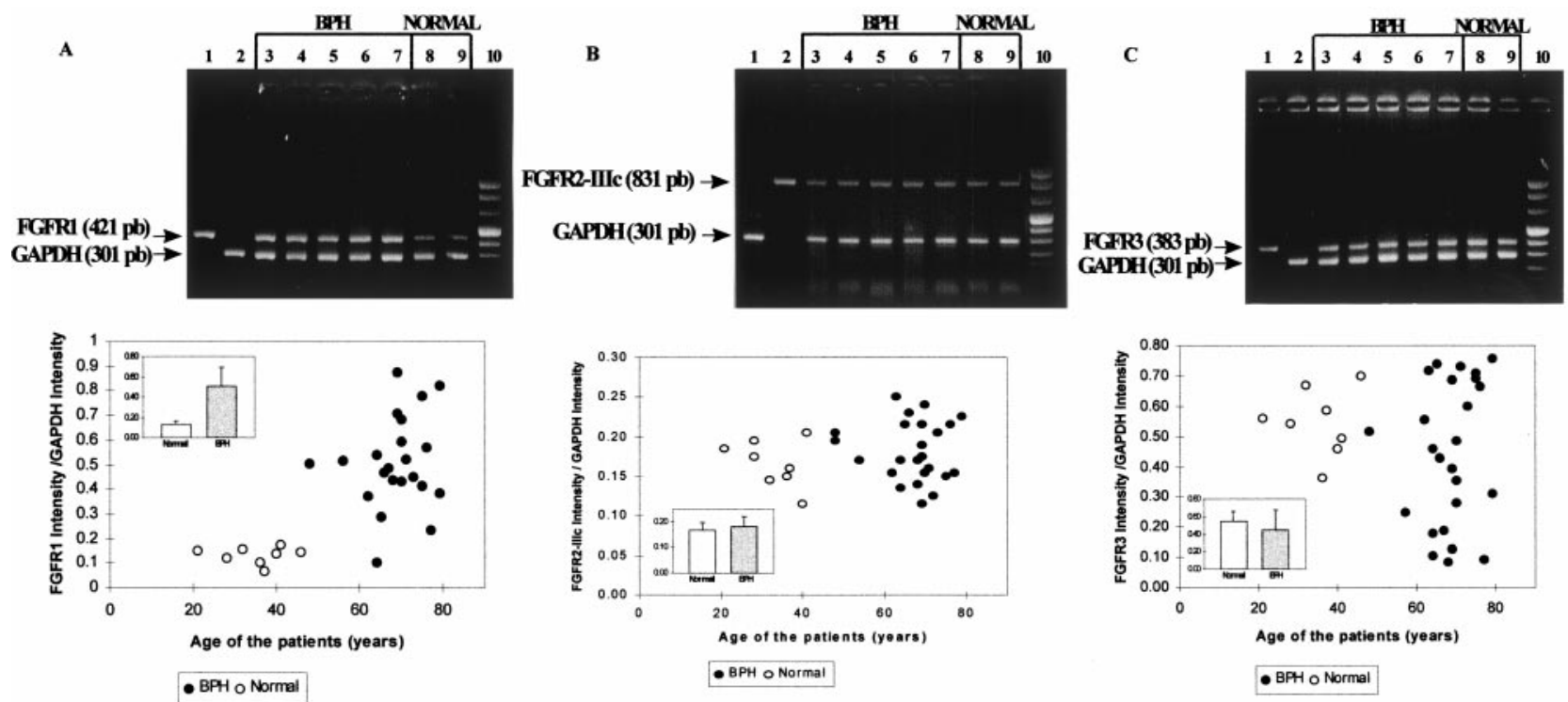

Figure 1 Amplification products of FGFR1 (A), FGFR2-IIIc (B), FGFR3 (C) and GAPDH mRNAs and their expression evaluated versus an internal standard (GAPDH) in 8 normal prostates and $25 \mathrm{BPH}$. Total mRNA was reverse transcribed and amplified by PCR. RT-PCR products were separated by electrophoresis, visualized with ethidium bromide (top panels) and analyzed by densitometry (bottom panels; Biolmage software). Lanes 1 and 2 are amplification products of FGFRs and GAPDH alone. Lanes 3 to 9 are co-amplification products of each FGFR with GAPDH as internal standard. The insets represent the mean values for normal prostates and for BPH ( \pm standard deviation). (A) FGFR1 gene expression is 2 to 8 times more important in BPH than in normal prostates. The difference between values in normal prostates and BPH is significant $(P<0.01)$ (identical results for 3 patients). (B and C) FGFR2-IIlc and FGFR3 genes expression shows no difference between normal prostates and $\mathrm{BPH}$. 

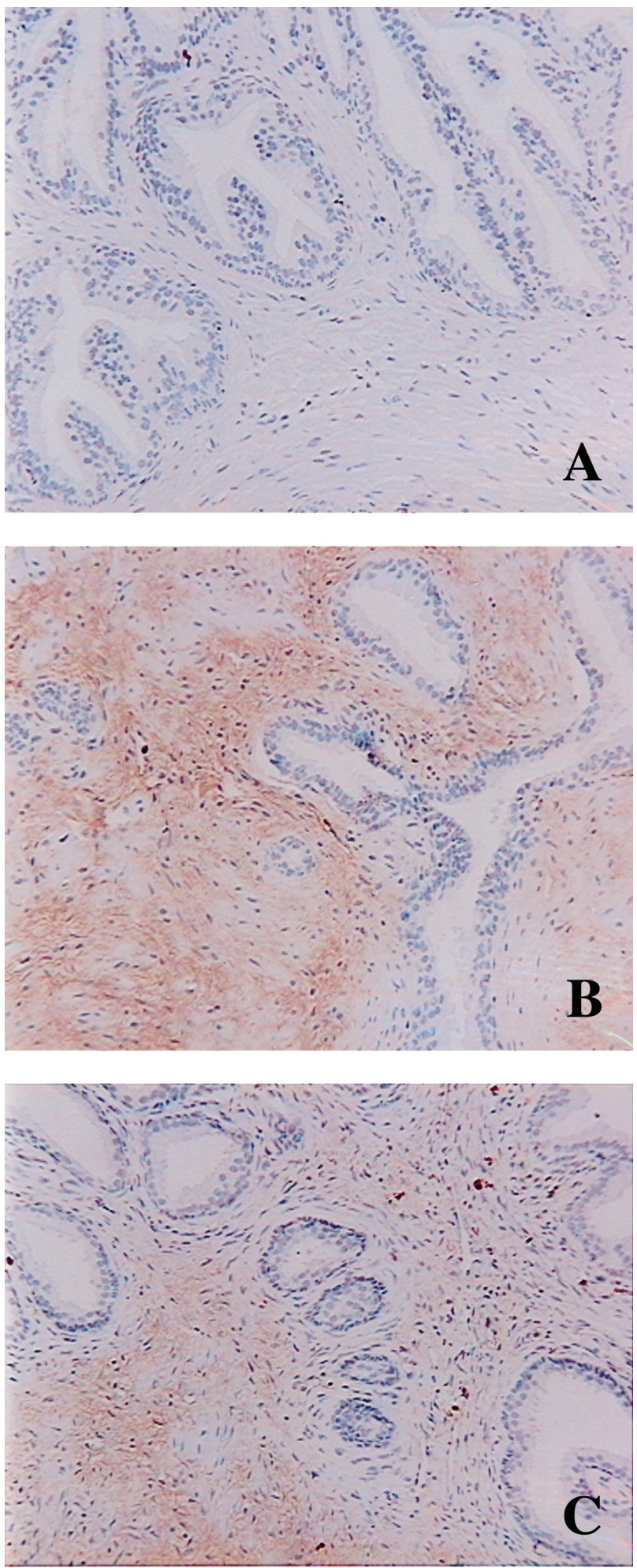

By RT-PCR, the size of the PCR products was as predicted. DNA sequencing of the amplified products for FGFR1, FGFR2-IIIc, FGFR 3 and GAPDH confirmed that they corresponded to the expected segments of targeted cDNA.

An over-expression of FGFR1 mRNA was observed in BPH compared with normal tissues (Fig. 1A). Densitometric analysis showed a two- to eightfold increase of FGFR1 expression in BPH. No correlation was observed between mRNA expression levels and the clinical and biological data of different patients. For example, 6 of the patients were treated with $\alpha$-blockers, 5 with Finasteride, 4 with plant extracts and 10 were not treated at the time of intervention, but mRNA expression did not seem to be influenced by the existence of a treatment. The size of the hyperplastic prostates was between 30 and $80 \mathrm{~g}$ and no correlation could be observed with mRNA expression. All the correlation studies (comparing mRNA expression with PSA levels, sampling weight, associated diseases, hyperplasia type...) were nil. Yet, the most important expressions were generally observed when the symptoms had occurred over a long period ( 5 to 15 years) and weak results were observed when the symptoms were recent (a few months). The mean FGFR1 mRNA expression was significantly higher in $\mathrm{BPH}$ than in normal prostates $(P<0.01)$.

For FGFR2-IIIb and FGFR3, no over-expression was observed as densitometric analysis showed no significant difference between BPH and normal population prostates (Fig. 1B and 1C).

\section{Immunohistochemistry}

For each patient, 3 fragments of prostate were obtained and at least 5 sections out of each fragment were tested. $\mathrm{Flg}(\mathrm{C} 15)$ is a polyclonal antibody raised against a peptide corresponding to the amino acids 802 to 822 mapping at the carboxy terminus of human FGFR1 receptor; it specifically recognises FGFR 1 and is not reactive with other FGFRs. All controls were negative. The preincubation of $\mathrm{Flg}(\mathrm{C} 15)$ with the corresponding antigenic peptide before immunohistochemistry showed no immunoreaction.

As in normal prostates, a brown staining was observed only in the stromal cells in BPH. The epithelial

Figure 2 Immunohistochemical localization of FGFR1. bFGF receptor was localized with a very specific primary antibody. A biotinylated secondary antibody fixed a streptavidin-biotinperoxidase complex. The immunoreactivity towards FGFR1 was visualized with DAB chromogen. Nuclei were counterstained with hematoxylin. Original magnification, $\times 100$. (A) Negative control for FGFR1. (B) Localization of FGFR1 in patient 8: it is localized in the prostatic stroma; no immunoreactivity was observed in the epithelium. Immunoreactivity is moderately positive. (C) Localization of FGFR1 in normal prostate. It is localized in stroma with a weak immunoreactivity. 

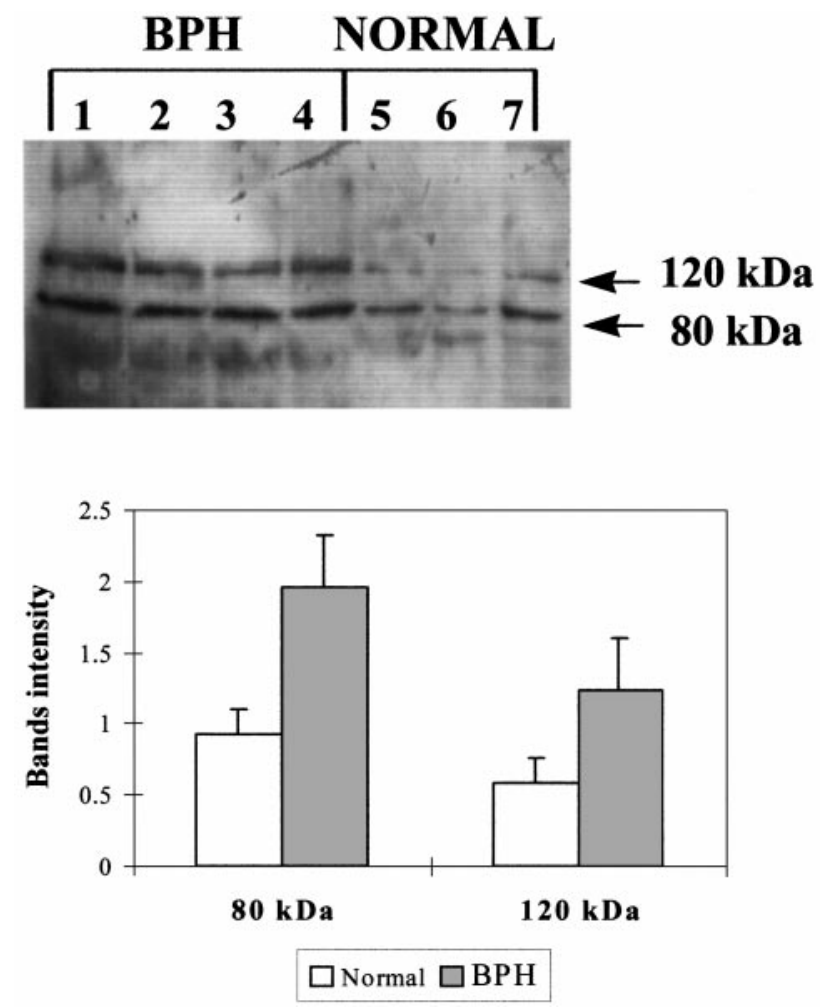

Figure 3 Total proteins were extracted, loaded on to polyacrylamide gel and transferred on PVDF membrane and incubated with a FGFR1 specific antibody. FGFR1 bands were visualized by chemiluminescence and analyzed by densitometry. Two bands of 120 and $80 \mathrm{kDa}$ were obtained and a 1.5 to 2.5 times over-expression of the protein FGFR1 was observed in BPH compared with normal tissues. Values presented are means \pm standard deviation.

tissue was not immunoreactive for FGFR1 (Fig. 2). The immunoreactivity was intense in almost all the $\mathrm{BPH}$ tissues showing important concentrations of this receptor. No correlation was observed between the intensity of staining and the clinical and biological data from patients. Yet we noticed that the immunoreactivity was all the more intense when the symptoms were of long standing.

\section{Western blot}

For each patient, the samples were studied in duplicate with similar results for each patient. All controls were negative and the preincubation of the $\mathrm{Flg}(\mathrm{C} 15)$ corresponding antigenic peptide prior to immunoblotting with the primary antibody showed no band.

Western blot analysis using antibody against FGFR1 showed 2 bands with molecular masses of about 120 and $80 \mathrm{kDa}$ which correspond to the expected sizes of the membrane receptor and the secreted form of FGFR1 respectively. Densitometric analysis showed a 1.5- to 2.5-fold over-expression of the protein FGFR1 (Fig. 3).

\section{Discussion}

The identification of growth factors implicated in abnormal cell proliferation is important in understanding the mechanisms of development of $\mathrm{BPH}$. Elucidating these mechanisms may have clinical and therapeutical import. Indeed, inhibiting the growth factors or the synthesis or activities of their receptors involved in this hyperplasia could be of great interest in the prevention and treatment of prostatic pathologies. This study was undertaken to evaluate the importance of bFGF receptors in the development of BPH.

This work was performed on 25 samples from patients with benign prostatic hyperplasia and on 8 normal samples from young unrelated patients undergoing vesical surgery and taken under exactly the same conditions as the BPH tissues. About 6 to $10 \%$ of the total removed tissue was studied.

The patient group greatly differed in age which is unavoidable as BPH symptoms appear at various ages. According to the Pathological Anatomy Department reports, no prostatic intraepithelial neoplasia-change has been observed in the studied prostates. Still, we have imagined that this important difference in age could be responsible for a modified endocrine control (modified androgenic impregnation) which could have effects on the expression levels of FGFRs. However, we did not find any link between age and FGFRs expression.

To our knowledge, the first study on FGFR1 in BPH was performed by Hamaguchi et al. (11) on a Japanese population and their results were approximately the same as ours as a fivefold increase was observed in FGFR1 expression in BPH compared with normal tissue. FGFR2-IIIc and FGFR3 were not quantified. In our study, a two- to eightfold increase in FGFR1 expression is compatible with this work. However, no over-expression of FGFR2-IIIc and FGFR3 genes was observed.

Ittmann \& Mansukhani (14) detected a moderate expression of FGFR 1 in the stromal cells from BPH tissues. They concluded that stromal cells expressed FGFR1, FGFR2-IIIc and FGFR3 and thus were stimulated by bFGF and aFGF, while epithelial cells expressed FGFR2-IIIb and FGFR3 and were reactive to FGF7 (KGF) and aFGF.

By immunohistochemistry, we found that only the prostatic stroma was immunoreactive for FGFR1. This result is still much debated. Indeed, while it is accepted that both stromal and epithelial cells synthesize bFGF and that this growth factor has a paracrine and autocrine action $(14,20)$, opinions differ about FGFR 1 localization. In some studies, FGFR1 was observed only in epithelium (12). Hamaguchi et al. (11) observed that FGFR1 was mainly localized in epithelium but also occasionally in stroma. Some authors propose that bFGF is responsible for cell proliferation and neovascularization both in stroma and epithelium through 
its receptor FGFR1 (13). Our results seem to support most studies (14-16) which find FGFR1 only in the stroma and not in the epithelium. bFGF, synthesized by stroma and epithelial cells, would act on stroma cells through its receptor, FGFR1.

Our results do not refute a possible action of bFGF on epithelium. Indeed, FGFR1 is the principal receptor for bFGF, but this growth factor can also be fixed on FGFR 3 at a lower rate. bFGF may also stimulate epithelium through its other receptors (20).

Moreover, these differences in FGFR1 localization could also be due to differences between the patients' origins, the protocol applied for localizing this receptor, the antibody origin etc.

We also observed that the immunoreactivity in immunohistochemistry was all the more intense as the duration of $\mathrm{BPH}$ symptoms was prolonged: more elevated results were generally observed when the $\mathrm{BPH}$ symptoms had lasted a long time.

Western blot analysis showed a more moderate difference in FGFR1 protein expression, as a twofold increase was observed in BPH when compared with normal prostates. These results support the work of Hamaguchi et al. (11) who found only a slight difference between BPH and normal tissues.

According to our results, the increase of FGFR1 in $\mathrm{BPH}$ tissue, associated with an increase in bFGF concentration, could potentiate cell growth and neovascularization implicated in the development of benign prostatic hypertrophy.

Concerning FGFR2-IIIb and FGFR3, as no significant difference in genes expression was observed between BPH and normal prostates, they may have a role in $\mathrm{BPH}$ through the over-expression of the ligand, but FGFR1, being over-expressed itself, probably takes a more important part in the development of the disease.

In normal prostate, bFGF is implicated in cell growth and neo-vascularization and is principally involved in physiological prostate growth at puberty and also in tissue reparation in adult human prostate (8). Lawson (20) presented two hypotheses to explain the increase of bFGF in BPH tissues. First, the dysregulation of endocrine and growth factors system and secondly, the many microscopic injuries during miction or infections, needing tissue reparation in the prostate.

In fact, prostate growth is under the direct influence of various growth factors such as FGFs, EGF, TGF $\beta$ (6), and the influence of androgens. An increase in bFGF and its receptor FGFR1 probably results in a dysregulation of cell proliferation potentiating abnormal prostate stroma growth. In BPH, not only bFGF but also KGF (FGF7) is over-expressed (21). KGF is the major growth factor expressed in the prostate (22); it is synthesized by the stroma and stimulates epithelial growth. The overexpression of this growth factor together with bFGF and FGFR1 could lead to disordered cell proliferation in the epithelium and in the stroma respectively.
Our studies are now directed to other FGFs, such as $\mathrm{KGF}$, and their receptors involved in normal prostate growth, which could be implicated in the development of $\mathrm{BPH}$.

\section{References}

1 Boyle P, Maisonneuve P \& Steg A. Decrease in mortality from benign prostatic hyperplasia: a major unheralded health triumph. Journal of Urology 1996155 176-180.

2 Guess HA. Benign prostatic hyperplasia: antecedents and natural history. Epidemiologic Reviews 199214 131-153.

3 Oesterling JE. Benign prostatic hyperplasia: a review of its histogenesis and natural history. Prostate Supplement 19966 6773.

4 Story MT. Positive and negative modulators of prostate cell proliferation. Biomedicine and Pharmacotherapy 199448 (Suppl 1) $35 \mathrm{~S}-41 \mathrm{~S}$.

5 Villers A, Griffith K, Eaton CL \& Habib FK. Anatomy of the prostate and pathogenesis of benign prostatic hyperplasia: role of hormones and growth factors. In Benign Prostatic Hyperplasia: Recent Progress in Clinical Research and Practice, pp 21-50. Eds K Kurth \& DWW Newling. New York: Wiley-Liss, 1994.

6 Desgrandchamps F \& Teillac P. The role of growth factors in the pathogenesis of benign prostatic hyperplasia. Biomedicine and Pharmacotherapy 199448 (Suppl 1) 19S-23S.

7 McKeehan WL, Wang F \& Kan M. The heparan sulfate-fibroblast growth factor family: diversity of structure and function. Progress in Nucleic Acid Research and Molecular Biology 199859 135-176.

8 Collins AT, Robinson EJ \& Neal DE. Benign prostatic stromal cells are regulated by basic fibroblast growth factor and transforming growth factor beta-1. Journal of Endocrinology 1996151 315-322.

9 Begun FP, Story MT, Hopp KA, Shapiro E \& Lawson RK. Regional concentration of basic fibroblast growth factor in normal and benign hyperplastic human prostates. Journal of Urology 1995 $153839-843$.

10 Mori H, Maki M, Oishi K, Jaye M, Igarashi K, Yoshida O \& Hatanaka M. Increased expression of genes for basic fibroblast growth factor and transforming growth factor type beta 2 in human benign prostatic hyperplasia. Prostate 199016 71-80.

11 Hamaguchi A, Tooyama I, Yoshiki T \& Kimura H. Demonstration of fibroblast growth factor receptor-I in human prostate by polymerase chain reaction and immunohistochemistry. Prostate 199527 141-147.

12 Sinowatz F, Amselgruber W, Lincoln D, Sasse J, Kolle S, Plendl J \& Kayser K. Role of basic fibroblast growth factor in prostatic tumors. Nutrition 199511 619-621.

13 Steiner MS. Role of peptide growth factors in the prostate: a review. Urology $1993 \mathbf{4 2} 99-110$.

14 Ittmann M \& Mansukhani A. Expression of fibroblast growth factors (FGFs) and FGF receptors in human prostate. Journal of Urology $1997157351-356$.

15 Sherwood ER, Fong CJ, Lee C \& Kozlowski JM. Basic fibroblast growth factor: a potential mediator of stromal growth in the human prostate. Endocrinology 1992130 2955-2963.

16 Saez C, Gonzalez-Baena AC, Japon MA, Giraldez J, Segura DI, Rodriguez-Vallejo JM, Gonzalez-Esteban J, Miranda G \& Torrubia F. Expression of basic fibroblast growth factor and its receptors FGFR1 and FGFR2 in human benign prostatic hyperplasia treated with finasteride. Prostate 199948 83-88.

17 Deshmukh N, Scotson J, Dodson AR, Smith PH, Ke Y \& Foster CS. Differential expression of acidic and basic fibroblast growth factors in benign prostatic hyperplasia identified by immunohistochemistry. British Journal of Urology $1997 \mathbf{8 0} 869-874$.

18 Daley SJ \& Gotlieb AI. Fibroblast growth factor receptor 1 is associated with neointimal formation in vitro. American Journal of Pathology 1996148 1193-1202.

19 Ferrer I \& Marti E. Distribution of fibroblast growth factor receptor-1 (FGFR1) and FGFR3 in the hippocampus of patients 
with Alzheimer's disease. Neuroscience Letters $1998 \mathbf{2 4 0} 139$ 142 .

20 Lawson RK. Benign prostatic hyperplasia and growth factors. Urologe Ausgabe A 199029 5-7.

21 Ropiquet F, Giri D, Lamb DJ \& Ittmann M. FGF7 and FGF2 are increased in benign prostatic hyperplasia and are associated with increased proliferation. Journal of Urology 1999162 595-599.

22 Planz B, Wang Q, Kirley SD, Lin CW \& McDougal WS. Androgen responsiveness of stromal cells of the human prostate: regulation of cell proliferation and keratinocyte growth factor by androgens. Journal of Urology $1998 \mathbf{1 6 0} 1850-1855$.

Received 19 December 2000

Accepted 4 May 2001 